\title{
Gender role in mangrove resource management: case study in Trieu Phong district of Quang Tri province, Vietnam
}

\author{
Vai trò Giới trong quản lý tài nguyên rù̀ng ngập mặn: Nghiên cứu truờng hợp \\ tại huyện Triệu Phong, tỉnh Quảng Trị, Việt Nam.
}

Research article

Nguyen Thi Hong Mai*, Dang Thai Hoang

University of Agriculture and Forestry, Hue University-Vietnam.

\begin{abstract}
A study on gender roles in mangroves management was conducted in Trieu Phuoc and Trieu Do communes of Trieu Phong district, Quang Tri province to gain a better understanding of gender roles in mangrove management. Research showed that local people are mainly dependent on fishing and aquaculture around the mangroves. Women have a good understanding about the role of mangroves and they are associated with mangroves not less than men, but so far their role has been overlooked. Mangrove management process seems to exclude women. This reduces the common management capacity of community. In addition, communities do not have a common regulation on the management and protection of mangrove forest resources and environment. A number of solutions are recommended such as strengthening the participation of civil society and women in mangrove forest management, developing a mangrove protection strategy and community-based regulations including gender.
\end{abstract}

Nghiên cưu về vai trò giới trong quản lý rùng ngập mặn (RNM) được thực hiện trên địa bàn 2 xã Triệu Phuớc và Triệu Độ của huyện Triệu Phong, tỉnh Quảng Trị nhằm có được sư hiểu biết hơn về vai trò giới trong quản lý RNM. Nghiên cúu đã chỉ ra rằng người dân ở đây chủ yếu sống dựa vào việc đánh bắt và nuôi trồng thủy sản tại khu vực RNM. Phụ nũ có hiểu biết khá tốt về vai trò crò RNM và ho gắn liền với RNM không kém nam giới, nhung cho đến nay vai trò của ho gần nhur không được nhìn nhận. Công tác quản lý RNM còn hạn chế nũ giới tham gia. Điều này làm giảm năng lực quản lý chung của cộng đồng. Ngoài ra các cộng đồng vẫn chura có quy uớc chung về quản lý, bảo vệ tài nguyên và môi truờng RNM. Tù đó nghiên cứu đề xuất một số giải pháp nhu tăng cuờng sự tham gia của các tổ chức dân sư và phư nũ trong quản lý RNM, xây dựng chiến lược bảo tổn RNM và các quy ước quản lý RNM dựa vào cộng đồng bao gồm giới.

Keywords: Gender role, mangrove-based livelihood, mangrove management.

\section{Introduction}

The central coast region of Vietnam with a coastline of $1200 \mathrm{~km}$ from Thanh Hoa to Binh Thuan province is most affected by the disaster (General Department of Hydrology, 2016). Recently, a report by German Watch pointed out that Vietnam is one of the 10 countries most affected by climate change in (Eckstein et al., 2018).

Quang Tri is a coastal province in Central Vietnam with a coastline about $75 \mathrm{~km}$, which is heavily influenced by extreme weather phenomena, especially natural disasters such as typhoons, floods and droughts which have in- creasing intensity, frequency and unpredictability (Minh Hien, 2017). Recognizing the role of mangroves in mainland and sea interaction, as one of the solutions to respond to climate change, the Quang Tri provincial authorities has promoted the development of mangroves in the estuaries of Hieu, Thach Han and Ben Hai rivers. However, the development of mangroves also faces many challenges. They are not only ecological risks but also socioeconomic threats including cutting down trees for firewood, expanding agricultural activities, especially rice farming and aquaculture as well everywhere (Tuan, 2014). Besides, in the process of preserving and developing mangroves, the role of gender is hardly mentioned. 
Many researches on gender roles in forest protection and management in Vietnam indicate that there is a need for equitable access to forest resources for both men and women to enhance the role and voice of women in forest management (Dien, 2011; Huu Minh, 2015). The Mangroves for the Future Program also recognizes that gender equality is the basis for conservation and sustainable development. In order to address gender issues to help the mangrove management achieve results, they have established gender as a cross-sectoral or strategic consideration in their program. The role of both men and women is important to the functioning and welfare of coastal communities (Mangroves for the Future, 2014).

This research was conducted to assess the participation and role of women in mangrove management and to find gender balance solutions towards sustainable management of mangroves in general and for Quang Tri Province as well as neighbouring provinces in particular.

\section{Materials and methods}

\subsection{Study sites}

The research was conducted in two mangrove communes: TrieuDo and TrieuPhuoc of TrieuPhong district, Quang Tri province.

\subsection{Methods}

Secondary data was collected from local agencies including the district's annual statistical yearbook. Reports on the natural and socio-economic conditions in the study area. The primary data was gathered through a survey of 80 households (HHs), focus group discussions (FGDs) and key informants interview.

Data is analyzed qualitatively and quantitatively together by using simple statistical method to calculate percentage and analyse the differentiation between male and female perception of mangrove role or impacts of mangrove to their careers.

\section{Results and discussion}

\subsection{Status of mangroves in study communes of Trieu Phong district, Quang Tri province}

Mangrove forest areas are located in three communes Trieu Phuoc, Trieu An and Trieu Do of Trieu Phong district, Quang Tri province. Crabapple Mangrove (Sonneratiacaseolaris) is the selected species mainly planted in these areas. Trieu Phuoc Commune started to grow and develop mangrove forests in 2011. Up to 2017, there are more than 35 hectares of mangrove forests stretching along the dyke of this commune While two communes Trieu Do and Trieu An planted mangroves in 2015- 2016 with a total area of 22 ha, and 6 ha respectively. Due to small area of planted mangroves and similar planting time with Trieu Do commune, so Trieu An commune was excluded for this study.
The distribution of mangroves areas in TrieuPhuoc commune are in the villages of DuyPhien, LuongKim, $\mathrm{AnCu}$, and Ha La in Trieu Phuoc commune (see Table 1), and in Trieu Do commune including in Quy Ha, An Da and Gia Doc villages (Table 2).

Table 1. Area of mangroves in TrieuPhuoc commune

\begin{tabular}{|c|c|c|}
\hline No. & Village & Area (ha) \\
\hline 1 & Duy Phien & 10.0 \\
\hline 2 & $\mathrm{Ha} \mathrm{La}$ & 20.0 \\
\hline 3 & Luong Kim & 3.0 \\
\hline 4 & $\mathrm{An} \mathrm{Cu}$ & 3.5 \\
\hline & Total & 36.5 \\
\hline
\end{tabular}

(Source: Statistical Office of the Commune People's Committee (CPC) of Trieu Phuoc, 2017)

Table 2. Area of mangroves in Trieu Do commune

\begin{tabular}{clr} 
No. & Village & Area (ha) \\
\hline 1 & An Da & 10 \\
2 & Gia Doc & 6 \\
3 & Quy Ha & 7 \\
& Total & 22
\end{tabular}

(Source: Statistical Office of the CPC of Trieu Do, 2017)

\subsection{Gender and mangrove-based livelihoods}

The interview of $80 \mathrm{HHs}$ in two mangrove communes of TrieuPhuoc and TrieuDo in TrieuPhong district showed that most of the interviewed HHs participated in fishing accounted for $77.5 \%$ and aquaculture accounted for $73.75 \%$ of surveyed HHs.

Local people also exploited some other products from the mangroves such as harvesting firewood, hunting birds, catching snakes or collecting vegetable for livestock, etc. Only $2.5 \%$ of the surveyed households do not have mangrove-based livelihood activities.

There are gender differences in mangrove-based livelihood activities. Men more participated in mangrove-based livelihoods than women. The participation of women in catching fish and shrimp in the mangroves was relatively high accounting $68.3 \%$ of fishing $\mathrm{HH}$ (see Table 3 ). The reasons are as following:

(1) Fishing activity requires healthy people to operate the machine, pull the net and row the boat, which are difficult for women to do. It also needs at least two persons: when one is fishing, the other keeps balance of the boat. Therefore, number of women involved in this activity is relatively high and they play supplemental role in this case.

(2) Men play a major role in aquaculture because this activity is difficult and highly risky. It requires experienced and knowledgeable people to control and soon discover problems to minimize the damage in aquaculture. 
(3) Gender division of labour in these two communes showed that women take in charge of housework, take care of family, sell products which the household collected from the mangroves. While men have responsibility for money earning activities.
(4) Exploiting other products from mangroves such as hunting birds, snakes is made by men; while women collect firewood and vegetables for daily meals. This also shows that activities of men in mangroves are more destructive than that of women.

Table 3. Mangrove-based livelihood activities of surveyed HHs

\begin{tabular}{llr} 
No. & Livelihood activities & $\begin{array}{c}\text { No. of HH } \\
\text { participat }\end{array}$ \\
\hline $\mathbf{1}$ & Fishing & 62 \\
$\mathbf{2}$ & Aquaculture & 59 \\
$\mathbf{3}$ & Collecting other products & 19 \\
$\mathbf{4}$ & Without mangrove-based & 2 \\
& \\
(Source: HH survey, 2017) & \\
&
\end{tabular}

\subsubsection{Gender perception on mangroves role:}

The survey and FGDs showed that the perception on the importance as well as the positive and negative impacts of mangroves development of both men and women in the community were similar. Both groups gave the following comments:

(1) Positive impacts fromMangrove development include: (i) Increasing the natural products because when the mangroves are developed, they attract many species such as fish, shrimp, crab, bird and create a favourable environment for aquatic species to breed; (ii) Protecting dykes, preventing impacts of flood to shrimp and fish pondsinaquaculture cultivation; (iii) Protecting environment and human health, mitigating the negative impacts of climate change; (iv) Efficiently using land resources protected by mangroves, especially building communitybased eco-tourism models taking advantage of the spatial relationship between Trieu Phong district and surrounding tourist sites.

(2) Negative impacts from Mangrove development include: (i) Garbage stored in the mangroves makes local people feel difficult to exploit fishery resources and pollutes water sources as well as causes water shortage supplying shrimp ponds; (ii) In the summer, there are many insects in the mangroves, which cause itching and affect quality of living water as well as health of local people. Fallen leaves change water color, causing rotten smell leading to reduced fish and shrimps; (iii) Strong growth of roots results in difficulties for catching fish/shrimp. The water surface was covered by the mangroves which compete space of fishering of fisher.

Local people are also unlikely to maintain and develop mangroves in the future if the pressure of food demand and cash income of water-based livelihoods increases.

Facing the limitations of mangrove development, local people tend to destroy the forest for catching fisheries, which makes challenges for effectively managing mangroves. It is clear that, there is a need for more effective and effective mangrove management in future.

\subsubsection{The impact of mangrove development on gender-based and community livelihoods.}

The research found that the local people in TrieuPhuoc commune likely to change their jobs more than TrieuDo one with a statistically significant level at $1 \%$. where the mangroves reach 7 years old and 2 years old respectively (see table 4).

Interviewing HHs about the scenario of job change when occurring disadvantages for fishing and aquaculture, up to $55 \%$ of surveyed $\mathrm{HHs}$ ( $44 \mathrm{HHs)}$ intend to change their jobs or take more jobs and $45 \%$ of surveyed HHs (36 $\mathrm{HHs}$ ) did not intend to change their jobs or take more jobs (Detailed in figure 1).

Table 4. Proportion of local people change their jobs when mangroves well grow

\begin{tabular}{ll} 
Observed communes & Changing job \\
\hline Trieu Phuoc & $34(85 \%)$ \\
Trieu Do & $10(25 \%)$
\end{tabular}

Non-changing job
$6(15 \%)$
$30(75 \%)$

Total
$40(100 \%)$
$40(100 \%)$

Test Chi-Square P-value $=0.000$

(Source: Author's estimates from field study data)

The analysis also showed gender differences in decision making for career change. Women seem to be more likely to stay with mangroves than men. This implies that when the scenario of job change occurs, it will affect men and women differently in which women are more vulnerable. 


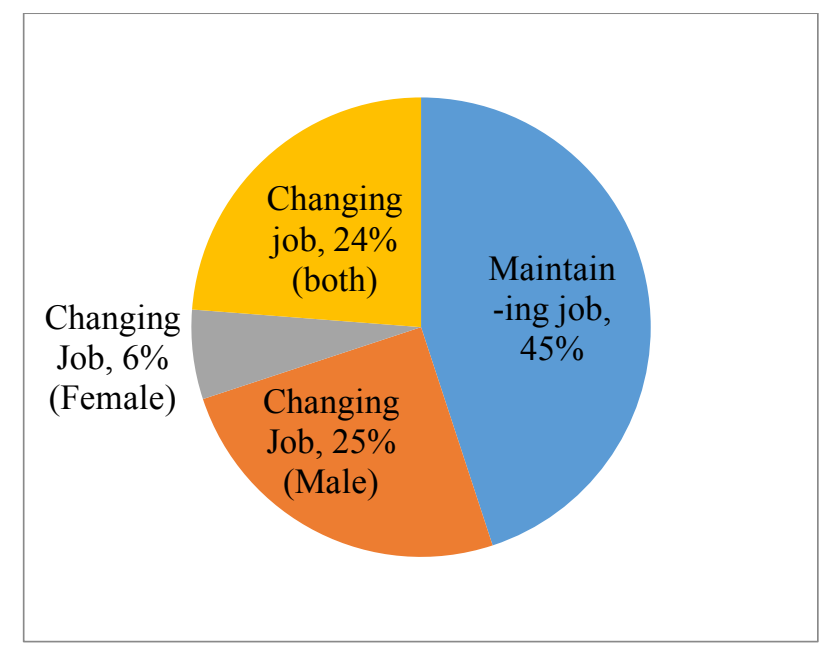

Figure 1. Gender differentiation in job change

\subsection{Gender differences in managing and protecting the mangroves.}

\subsubsection{Forms of mangrove forest protection in the study area}

- Two or three members per village were chosen to formulate the protection team by the Commune People's Committee. This team patrols the mangroves periodically or suddenlyto detect the problem and help to protect mangroves effectively.

- The Commune People's Committee also assigns and involve $\mathrm{HHs}$ in forest management by giving them the right to fish in the mangroves. This way is highly appreciated by local people, as their main working time is inside or nearby the mangroves. It make them easily detect problems that are going on and solve it in the soonest and most effective way.

- The project supports making the fences to prevent the forest from being destroyed by people activities and cattle.

\subsubsection{Gender participation in forest management and protection}

In 80 surveyed $\mathrm{HHs}$, only $30 \%$ of $\mathrm{HHs}$ participated in mangrove planting. Among the households involved in plantation, $100 \%$ of women participated in mangroves plantation with their family.

Participation in forest management and protection of local people is still limited, only $46.3 \%$ of surveyed HHs (37 $\mathrm{HHs}$ ) are involved in mangrove forest management, in which there are no women. Some reasons justifying the lack of women in this activity are that: (1) Men have a greater voice than women in dealing with any problem; (2) Women take in charge of housework, take care children, so they have no time and are not strong enough to participate in forest management; and (3) Because of the initial selection of the Commune People's Committee, the management and protection of the forest is only for male.

\subsection{Factors affecting gender differences in mangrove forest management}

\subsubsection{The organizational structure supports the management and protection of mangroves}

The organizational structure of mangrove forest development in the study area is as follows (see figure 2):

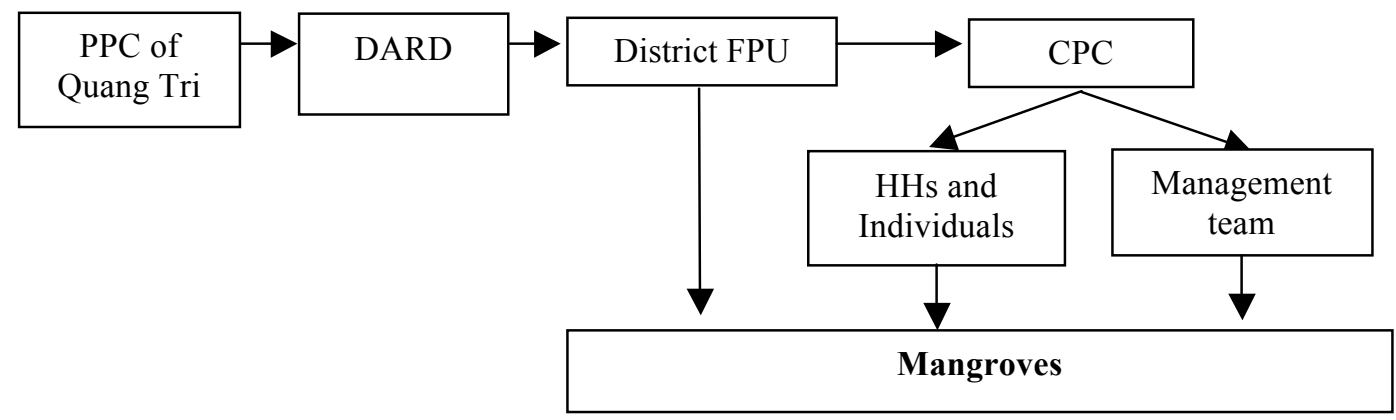

Figure 2. Model of mangrove resource management in the Trieu Phong district

Provincial level: Provincial People's Committee (PPC) instructs Department of Agriculture and Rural Development (DARD) to be the investor to carry out forest plantation activities. Forest management in the first year is mainly implemented by the project. From the second year onwards, when the mangroves have developed steadily, the forest management has been handed over to the commune.

- The CPCs of Trieu Phuoc and Trieu Do support by setting up protection teams, paying allowance for mangrove management. They organize meetings to disseminate information on forest management and protection to the local communities. The CPCs also grant fishing rights to the people who are involved in management of mangroves. In addition, they mobilize local people to gather rubbish from the mangroves. It can be said that, CPCs take in charge of almost activities related to mangrove management and lack involvement of mass organizations.

- The District Forest Protection Unit (FPU) is responsible for managing and sanctioning acts which are harmful to forests; assists the CPCs in guiding regulations and 
policies on forest management; periodically surveys the growth, development of the mangroves; and resolves problems occurring in forest management process.

- Teams, individuals or HHs involved in mangrove protection and management are paid or entitled to exploit natural resources in the mangroves.

Through the interview process, gender inclusion was not recognized by the relevant authorities who directly involved in the monitoring and control of the mangrove forest management process. Women roles are almost ignored in mangroves maintenance when the project finished.

\subsubsection{Gender division of labour}

Table 5. Gender-based activity framework
The survey on gender division of labor was conducted to identify the production activities of men and women associated with natural resources, at the same time to understand the level and duration of these activities impacting on those resources (detailed in Table 5).

There is a clear division of activities between women and men:

- In fishing and aquaculture activities, men are usually the main participants while women only play a supporting role.

- Female involve in small business such as selling products harvested from the mangroves, and men are less involved in.

\section{Location}

\begin{tabular}{|c|c|c|c|}
\hline & & & \\
\hline Mangroves & $\begin{array}{l}\text { Fish trapping } \\
\text { Fish netting } \\
\text { Electric fishing } \\
\text { Aquaculture } \\
\text { Food collection } \\
\text { Fodder harvest } \\
\text { Fuel wood gathering }\end{array}$ & $\begin{array}{l}\text { Male } \\
\text { Male/Female } \\
\text { Male } \\
\text { Male } \\
\text { Male/Female } \\
\text { Female } \\
\text { Female }\end{array}$ & $\begin{array}{l}\text { 19h-22h/day/year } \\
8 \mathrm{~h}-9 \mathrm{~h} \text { and } 16-17 \mathrm{~h} / \text { day/year. } \\
7 \mathrm{~h}-10 \mathrm{~h} / \text { day/sometimes } \\
3 \text { hours/day and guard at night } \\
3 \text { hours per day } \\
2 \text { hours/day/sometimes } \\
\text { In flood season }\end{array}$ \\
\hline Paddy & $\begin{array}{l}\text { Soil preparing } \\
\text { Rice sowing } \\
\text { Weeding } \\
\text { Harvesting }\end{array}$ & $\begin{array}{l}\text { Male/Female } \\
\text { Female } \\
\text { Female } \\
\text { Male/Female }\end{array}$ & $\begin{array}{l}6 \mathrm{~h}-10 \mathrm{~h} \text { and } 14 \mathrm{~h}-15 \mathrm{~h} \text { per day/week/season } \\
2-3 \text { days/season } \\
6 \mathrm{~h}-11 \mathrm{~h} \text { and } 13 \mathrm{~h}-15 \mathrm{~h} / \text { day at } 4 \text { weeks old of rice } \\
\text { Whole day at harvest season }\end{array}$ \\
\hline Garden & $\begin{array}{l}\text { Soil preparing } \\
\text { Crop planting } \\
\text { Weeding, fertilizing } \\
\text { Harvesting }\end{array}$ & $\begin{array}{l}\text { Male/Female } \\
\text { Female } \\
\text { Female } \\
\text { Female }\end{array}$ & $\begin{array}{l}1 \text { week } \\
2-3 \text { days per crop } \\
2 \text { days/month } \\
2 \text { hours/day }\end{array}$ \\
\hline Market & $\begin{array}{l}\text { Buying products } \\
\text { Selling products }\end{array}$ & $\begin{array}{l}\text { Female } \\
\text { Female }\end{array}$ & $\begin{array}{l}\text { Morning/every day } \\
\text { Morning/every day }\end{array}$ \\
\hline House & $\begin{array}{l}\text { Cleaning up } \\
\text { Cooking } \\
\text { Washing clothes, cleaning } \\
\text { farm animals } \\
\text { Feeding animal } \\
\text { Repairing household items } \\
\text { Caring children }\end{array}$ & $\begin{array}{l}\text { Female } \\
\text { Female } \\
\text { Female } \\
\text { Female } \\
\text { Male } \\
\text { Male/Female }\end{array}$ & $\begin{array}{l}\text { 4h-6h/every day } \\
\text { In the early morning and evening } \\
\text { After dinner in summer season } \\
\text { On the day in winter season } \\
3 \text { times per day } \\
\text { Sometimes } \\
\text { Every day }\end{array}$ \\
\hline
\end{tabular}

(Source: Field survey, 2017)

- In agricultural production, men often take in charge of planning and harvesting, while the rest kinds of work are usually done by women, such as caring and selling products.

- In reproductive activities, women play a key role and men play a supporting role.

- In community activities, men are the main participants and women only attend when their husbands can not participate.

In sum up, the division of labour by gender presents limitations on the role of women. Women have less oppor- tunity to participate in community activities. They are passive in the management and use of local resources. Obviously, they have no voice in managing these resources. So if occurring any competition in relating to mangroves they are passive to cope with.

\subsubsection{Gender in livelihood resource access}

The survey results show that men are head of HHs and have greater access to resources, which in turn has a greater understanding of issues than women (table 6). 
Table 6. Gender in livelihood resource access

\begin{tabular}{clll}
\multicolumn{1}{c}{ Resources } & \multicolumn{1}{c}{ Access } & \multicolumn{1}{c}{ Control } & \multicolumn{1}{c}{ Benefit } \\
\hline \multirow{2}{*}{$\begin{array}{l}\text { Langroves } \\
\text { Garden }\end{array}$} & Male/Female & Government & Animal feeds, food, income \\
Paddy & Male/Female & Head of HH & Vegetables, food, income \\
Aquaculture land & Male/Female & Head of HH & Food, income \\
Social capital & Male & Head of HH & Income, Food \\
Knowledge & Male/Female & Head of HH & High mobility, easy to switch jobs \\
Financial capital & Male/Female & Head of HH & $\begin{array}{l}\text { Help overcome difficulties, develop economy, improve } \\
\text { material and spiritual life }\end{array}$
\end{tabular}

(Source: Field survey, 2017)

Men dominate most of the livelihood resources and benefits. The involvement of women in controlling, distributing and benefiting of those resources is limited. Women access only some resources that are linked to genderbased labour division. Facing natural disasters, therefore, women are more vulnerable, reduced livelihoods and more depend on men.

\section{Conclusion and recommendation}

\subsection{Conclusion}

The development of mangrove has been recognized not only by local authorities but also by local communities. Mangroves in the studied communes have been developing quite well, formulating green belts to protect dykes and supplying water to shrimp ponds in the area. However, for HHs with mangrove-based livelihoods for natural fishing, the amount of fish and shrimp tends to decline due to the destructive fishing and the competition between mangrove development and water surface.

Research has shown that women's role in access to mangrove management and using its resources is often limited, overlooked or under-valued, so they are unable to bring into play their own capacity. Meanwhile, both men and women have unique perspectives on why mangroves are important and how to protect them. Therefore, when both men and women join in mangrove protection, it may lead to more positive results.

Women are fully involved in mangrove plantation, interested in what harvested from forest for their daily life and involved in the exploitation of natural aquatic resources. They are worried when the forest is polluted but they have no voice in mangrove management. So once women are recognized their role in management, they will be ready to implement conservation measures, using their knowledge of forest products to better manage mangroves.

In terms of mangrove management and protection in the district, there are not many policies to support livelihoods in order to better manage the mangrove. The local government does not guilde local people to build up the regulation for mangrove environment management and protec- tion. The research also found that it is really very few local people participate in mangrove management.

\subsection{Recommendation}

Mangroves play an important role in mitigating and adapting to the impacts of global climate change. Building the strategy for mangrove management is necessary but it should consider factors as follows:

In order to preserve and sustain mangroves, it is imperative to establish and strengthen the collaboration and participatory of civil society organizations to increase the voice of women and marginalized people.

The role of local people, gender, rights and local governance should be considered equally.

In mangrove conservation strategy, it should consider potential or negative impacts on vulnerable groups such as women due to the mangrove restoration and development.

Communes and villages need to have regulations on mangrove protection so that they can promptly handle the violations that the local people as well as external factors can cause and affect the forest.

In choosing the protection team and organizing training courses on forest protection and management, it should involve local people in considering gender issues.

\section{References}

[1] Tuyen, V.D. and Dien, L.T., 2011. Research on the role of gender in community forest resource management and restoration in Thuong Quang Commune, Nam Dong District, Thua Thien Hue Province. Journal of Forestry Science, Vol. 3, 2011.pp. 1907-1913 (in Vietnamese).

[2] Eckstein D., Künzel V., and Schäfer L., 2018. Global Climate Risk Index 2018. Germanwatch e.V: Bonn.

[3] Huu Minh, 2015. Research on the women role in 
management and use of forest resources in Xuan Nha Natural Reserve. Internet access: http://nature.org.vn/vn/2015/05/nghien-cuu-ve-vaitro-cua-nguoi-phu-nu-trong-quan-ly-su-dung-tainguyen-rung-o-kbttn-xuan-nha/ (in Vietnamese)

[4] Mangrove for the Future, 2014. Gender equality. Internet access: https://www.mangrovesforthefuture.org/topics/crosscutting/gender-equality/

[5] Minh Hien, 2017. Mangrove development and protection in Quang Tri. Internet access: http://quangtritv.vn/tin-tuc-n4971/phat-trien-va-baove-rung-ngap-man-o-quang-tri.html_(in Vietnamese)
[6] Srinath, 2008, Challenging The "Man" In Mangroves: The Missing, Role Of Women In Mangrove Conservation.

[7] General Department of Meteorology and Hydrology, South Central region, 2016. Central Vietnam will be heavily influenced by Climate Change. Internet access: http://kttvntb.gov.vn/Doc.aspx?d=525_(in Vietnamese).

[8] Tuan, L. X., 2014. Proposing some measures to protect mangroves in 8 provinces of the North Vietnam. Journal of the Environment, Vol. 5/2014 (in Vietnamese). 